\title{
We, Teacher Trainers in a Federal Institute: Narrating the Woven Practices in Collaboration
}

\author{
Rosenilde Nogueira Paniago, Patrícia Gouvêa Nunes, Josiane Medeiros, \\ Renata Pamplona, Calixto Junior
}

Instituto Federal Goiano, Centro de EducAção Rosa de Saberes, Goiás, Brazil

Email: rosenilde.paniago@ifgoiano.edu.br

How to cite this paper: Paniago, R. N., Nunes, P. G., Medeiros, J., Pamplona, R., \& Junior, C. (2021). We, Teacher Trainers in a Federal Institute: Narrating the Woven Practices in Collaboration. Creative Education, 12, 103-121. https://doi.org/10.4236/ce.2021.121008

Received: June 7, 2020

Accepted: January 16, 2021

Published: January 19, 2021

Copyright (c) 2021 by author(s) and Scientific Research Publishing Inc. This work is licensed under the Creative Commons Attribution International License (CC BY 4.0).

http://creativecommons.org/licenses/by/4.0/

\section{(c) (i) Open Access}

\begin{abstract}
This article is about being a teacher training in the biological sciences and chemistry degree courses at a federal institute of education. It results from research, whose objective was to develop a training proposal that focuses on the articulated planning between some disciplines offered in the teacher trainers and on the development of the supervised curricular internship (ecs) as a viable element of the articulation between the teaching, research and extension tripod and the future licensee's field of work. This is a qualitative research carried out by a group of professors working in undergraduate courses and with research on initial teacher training, in which the narratives collected in portfolios prepared by the graduates of the biological sciences and chemistry courses and the authors' narratives based on observation of teaching practices carried out in the classroom and in research and extension projects, of which they are coordinators. The results signaled that the collaborative planning and the materialization of the teaching/research/extension tripod having as object the pedagogical situations of the school of basic education in the process of the sci, promote an articulated formation between the diverse disciplines of the training course and approximation with the professional context, the school of basic education.
\end{abstract}

\section{Keywords}

Initial Teacher Education, Teacher Training, Collaborative Planning,

Supervised Curricular Internship, Teaching, Research and Extension Projects, Práxis

\section{Introduction}

The present discussion is in the field of teacher training focusing especially on 
the praxis developed by the authors in the undergraduate teaching courses of a Federal Institute, during the years 2017 to 2019 . Teacher training and the processes of learning construction have occupied a prominent place in academic and political discussions, in view of the multiple demands, in socio-educational, political, economic and environmental terms (Paniago, 2016). This is a situation that demands new proposals in the institutions that offer initial training courses in order to contemplate such requirements.

Despite the need for new proposals in the initial training of teachers, currently, undergraduate teaching courses have faced challenges, such as the lack of professional expectation of undergraduates, added to the teaching practices of teachers, sometimes embodied in homogeneous, repetitive methodologies that do not contemplate the different forms of learning, study/work relationship and socio-cultural situations, in which the undergraduate students are immersed (André et al., 2010). Another challenging factor is the fragmentation between the disciplines that make up the curricular matrix of the courses and the disconnection between the teaching practices of the course and the future field of work of the undergraduate students, the daily routine of the basic education school. "There is still a prevalence of the historic idea of offering training with a focus on the specific subject area, with little space for pedagogical training in undergraduate courses" (Gatti, 2010: p. 1372).

If this problem occurs in the context of HEIs (Higher Education Institution) that already have extensive experience with teacher training, this scenario is worsened in the context of the Federal Institutes, which now offers undergraduate courses in the areas of Biological Sciences, Chemistry, Pedagogy and Mathematics from Law no. 11,892/2008, which obliges Federal Institutes to offer a minimum of $20 \%$ (twenty percent) of their vacancies for undergraduate courses. The inability of the institution to train teachers, coupled with the inexperience ${ }^{1}$ of many of the teachers with the issues of teaching and research linked to basic education, challenges the implementation of collaborative teaching practices linked to the daily routine of the basic education school.

Thus, the formative scenario in undergraduate courses demands the effective exercise of new teaching practices that, in addition to being operationalized in an articulated way in the different disciplines of the curricular matrix, it is important to be carried out in a collaborative way among teachers and linked to the daily life of the public school basic education, future field of work for undergraduates. In this direction, since 2018, a group of professors who work in undergraduate courses and with research on initial training, at the institution, the research locus, have been developing a research project whose focus is the teaching initiation practices that occur in the Supervised Curricular Internship and in the disciplines that offer Practice as a Curricular Component (PCC). To this end, the

\footnotetext{
${ }^{1}$ In order to enter undergraduate teaching courses, production in the field of education and experience in basic education are not required, considering that the teacher will work at various levels and modalities of teaching (technical high school, Proeja (basic education in the modality of education of young people and adults), higher education and post-university graduation courses).
} 
group initially investigated the models of practices of insertion into teaching, with emphasis on the internship and the PCCs (Paniago et al, 2018), and in sequence, insertion actions were developed in the perspective of collaborative planning, articulated between some disciplines and the research bias. Soon the data that will be presented here, it is an excerpt, whose objective was to present elements that contribute to the articulated planning between the disciplines, highlighting the contributions of the Supervised Curricular Practice (SCP) as an element that enables the connection between the teaching tripod, research and extension and the future field of work of the graduates. Other results have already been presented by the researchers (Paniago et al., 2020).

We assume that the SCP is a fruitful space for the learning of teaching in undergraduate courses and getting closer to the everyday life of the basic education school, the future field of work for undergraduates. Furthermore, it is a context that requires audacity from the trainers when implementing training alternatives.

\section{Methodology}

In this qualitative research, we use the assumptions of action research, in the sense of Alarcão (2011), Imbernón (2016) and Zeichner (2008). Alarcão (2011) contributes by pointing out that one of the strategies that has been developed by trainers is action research, which has great formative value for the development of teachers' autonomy and reflection in the work context. According to the author, "[...] the action research methodology" has the following important characteristics: "[...] a) the contribution to change; b) the participatory, motivating and supportive character of the group; c) the democratic impulse" (Ibid., p. 50). In turn, Imbernón (2016) defends action research in the training process as a powerful teacher training strategy, as it allows collaborative actions, teamwork to achieve goals that benefit everyone. "Action research has the possibility of compromising and transforming the knowledge of teachers and research teachers of themselves, directly urging them to reconstruct and transform their daily practice and, in addition, to theorize and permanently review their educational processes" (Ibid., p. 199). And, finally, we also rely on Zeichner (2008) in view of his experience with action research, as a training strategy, in order to help future teachers to develop theories about teaching and the struggle for social justice. For the author,

Action research does provide a means for teachers in training to engage in the analysis of their own teaching practice so that such analysis can become the basis for deepening and expanding their thinking and, consequently, to include a look about the social and political dimensions of their work. It can do this in a way that minimizes the degree of strategic obedience on the part of the internship students, and that it can begin to build an authentic commitment by the teachers in training about working for social change in their classroom practice. (Zeichner, 2008: p. 85)

Therefore, in this research registered with the ethics committee of Plataforma 
Brasil, Opinion n. 2,758,368, we use, as a data collection procedure, our own narratives and the graduates' narratives registered in the portfolio, these elaborated in the disciplines that we teach and in the research and extension projects that we coordinate. Despite the fact that all participating undergraduate students prepare a portfolio, for the purposes of clipping, we selected some whose narratives are representative of the activities developed in the teaching of Science, Biology and Chemistry, through projects in 3 public schools of basic education (School A, B and C), which will be identified here with fictitious names. From Biological Sciences, we have Paulus, Nanes, Loura and Branca; from the Chemistry Course, we have Tamara, Fernando and Taila.

The data presented here are, therefore, based on the oral and written narratives of the researchers and undergraduates involved. These, in turn, are also formative, since, when narrating, all involved ones may recall the experiences and provide them with new meanings. When narrating the story, the various experiences, all of us, authors and participants, we shape new experiences in the process, because we can reflect on it. Certainly, in addition to using the narratives to elucidate what was experienced in the research, they were used in our formative moments and also in the classroom, as we motivate the participants to talk about lived experiences, which, for Josso (2010: p. 34) “[...], it is, therefore, a certain way of telling yourself your own story, your personal and socio-cultural qualities, the value that is attributed to what is 'lived' in the temporal continuity of our psychosomatic being".

We emphasize that the use of narratives is anchored especially in Abrahão and Passeggi (2012: p. 61), by emphasizing the importance of narratives in initial and continuing education, "[...] in the sense that the act of making explicit for himself and for the other, the learning processes, adopting a critical position, are likely to lead the person who narrates the understanding of the historicity of his learnings and, therefore, to self-regulate his ways of learning in an emancipatory direction". Thus, in addition to making use of narratives in the training process of our undergraduates as trainers, when narrating our training experiences in the present text, we reflect on our teaching praxis with a view to (re)meaning it.

The text proceeds outlined as follows: initially, we will have a general discussion about some aspects of the initial teacher education, knowledge and teaching professional identity, about the professional development and teaching learning at school and, finally, we will present the work experience in which we highlight the collaborative planning and the SCP as an enabling space for teaching learning and the articulation of the teaching, research and extension tripod with the insertion of undergraduate students in the daily routine of the basic education school.

\section{Initial Teacher Education, Knowledge and Professional Development}

In previous works, author [15] it is emphasized that, at present, there are still 
proposals for initial training aimed at technical rationality, in which teachers are workers, transmitters and reproducers of knowledge produced by people who are often unaware of the various relationships that take place in the school routine. This is a model still present in most teacher training curricula in Brazil (Diniz-Pereira, 2016). In the same direction, Tardif (2013) points out that

Until now, the training of teachers has been dominated, above all, by disciplinary knowledge, knowledge that is usually produced in a glass bell jar, with no connection with professional action, and must then be applied in practice through internships or other activities of the genre. This disciplinary and applicationist view of professional training is meaningless today, not only in the field of education, but also in other professional sectors.

(Tardif, 2013: p. 23)

In contrast to this model, according to Paniago e Sarmento (2015), there is an intense movement of training trends that focus on the professional development of teachers, as critical, reflective, investigative professionals. It is the teachers immersed in the different complex situations of the classroom and the school routine that have the property to think and resolve the ambiguous and uncertain situations that arise. Therefore, it is necessary that they are prepared in the initial training for the development of research and didactic interventions in order to face the various problems with the teaching-learning process of children, youth and adults. In this formative perspective, to which we subscribe, the teaching praxis is embodied in a process of action, problematization, reflection, analysis and systematization of practices in the light of existing theories. The theory, in this case, will serve to support (re)thinking and (re)formulating the pedagogical practice and not just to be reproduced. Tardif (2013) proposes that professors make an effort to appropriate research and produce it, reformulating their speeches and those of the group, considering their needs, in a language subject to objectification. "If teachers are effectively subjects of knowledge, they must make the effort to act as such, that is, the effort to become actors capable of naming, objectifying and sharing their own practice and professional experience" (Tardif, 2013: p. 240).

We understand that initial training based on the principles of technical rationality is no longer useful for the current moment, when advances in science and technology, diversity, ambiguous relationships in school routine require professionals to mobilize various knowledge to face these situations. Tardif (2013) warns that it is imperative to stop considering teachers as technicians who apply knowledge produced by others. Gómez (1997) also points out the limits and gaps in the formative perspective of technical rationality and justifies the impossibility of fitting social reality into pre-established schemes, as the phenomena have, as characteristics, uncertainty, instability, complexity, singularity and the conflict of values.

Brzezinski (2011) also contributes by defending teacher education as a process marked by the complexity of knowledge, by criticism, by reflection-action, by 
creativity, by the recognition of the cultural identity of those involved in training processes and by the relationships established in the mediation between trainers and learners. Flores (2000) also contributes by elucidating that

Training the teacher, as a social actor, who adapts himself to the reality in which he intervenes in a participatory way, implies an appreciation of cooperation practices during the training periods and the promotion of experiences that promote the development of a participative conscience. On the other hand, there is a need for a holistic and integrative view of the training processes, overcoming the disciplinary perspective, in the sense of promoting a critical attitude that fosters the self-reflective dimension of knowledge. (Flores, 2000: p. 149)

Based on the above, we advocate training that ensures and promotes the production of knowledge, always recognizing the future teacher as a subject and not just an individual, that is, a subject that is made by making history. A subject who is involved in society, thus being able to recognize the role that the school has in relation to itself. It is in this context that one should reflect on the training of this professional who is working in this school intertwined with the world around him. That is the challenge of how to train this professional who will prepare the student for social life.

Brzezinki (2011) also argues that being a teacher implies multidisciplinary knowledge, that is, scientific, pedagogical, cultural, political and transversal knowledge that favors the multi, inter and transdisciplinarity, which must occur in the formation process of one's training. This allows the student internal maturation and a solid knowledge and practices that give him/her theoretical preparation and skills to develop teaching work and a certain professional emancipation to exercise the profession.

Finally, knowing that the initial training is insufficient for the preparation of the necessary learning to face the innumerable challenges of the teaching work, we call for at least the seven dimensions of knowledge which are essential to the teaching praxis to be guaranteed. They were presented in the Rosa dos Saberes, necessary to professional teaching, which was defended by us previously:

1) the content of the training area, an essential condition in teaching; 2) pedagogy of content; 3) the curriculum and the Sciences of Education; 4) about the student and the way he/she learns; 5) the context and the educational community; 6) reflection and investigation practices; 7) about inter and transdisciplinarity. (Paniago, 2017: pp. 80-81)

We therefore defend the importance of teachers mobilizing knowledge in the classroom that goes beyond the knowledge of the contents of their area of education, from the pedagogy of the content to the knowledge of the various Sciences of education (Didactics, Socio-Historical Foundations, Socio-Philosophical Foundations of Education, Educational Policies, Curriculum, among others). In addition, we emphasize the importance of critical, political and transdisciplinary stance 
that translates into affective sensitivity, loving openness to look at life, oneself and the other, especially the student (Paniago, 2016, 2017). In the set of knowledge, we highlight the need for teachers to conduct research in pedagogical practice with a view to improving the quality of teaching and learning and their own professional development.

In this discussion, we understand that the professional development of teachers refers to the learning acquired throughout life, and as we explained,

Professional development and the identity of teachers translates into the continuous learning of teaching, in a temporal perspective, throughout life and influenced by several actors: personal, professional experience, training processes and socio-cultural, economic, political and environmental aspects, in which I highlight the importance of developing reflective and investigative practices for teachers, who can mobilize the knowledge necessary for the exercise of teaching and for their professional development. (Paniago, 2016: p. 140)

Furthermore, when focusing on the professional development of teachers as reflective and researchers, we understand that the school, the future field of work of the undergraduates, is a fundamental space to be considered in this formative perspective, as it is a matrix of multiple learning and knowledge about teaching. As Mizukami (2013: p. 23) defends by pointing out that “[...] par excellence, the school is a place for learning and professional development of teaching". Also in this context, Alarcão (2011: p. 12) states that "[...] it is necessary to invest well, deepen quality, make a lot of connections with schools and create learning communities for teachers who are in schools and, if possible with teachers who are learning to be teachers".

In addition to advocating training based on research and reflection, linked to teaching work, we advocate collaborative work, considering that dialogue and collective actions give rise to thinking and doing together, considering that, as stated by Alarcão (2011: p. 34). "The development of a critical spirit takes place in dialogue, in the confrontation of ideas and practices, in the ability to listen to the other, but also to listen to oneself and to self-criticize. And all of this is only possible in a human environment of understanding acceptance [...]". According to the author (Ibid. P.63), teachers cannot be isolated in the classroom, on the contrary, while collaborating "[...] they have to build thinking about the school what is lived in it. It is in this context that study circles and discussion groups on hot topics gain strength".

In emphasizing the importance of approaching the reality of the basic education school in the SCP in an intentional, reflective way, Pimenta and Lima (2017: p. 36) point out that "it is necessary that the supervising teachers of the internship proceed with the collective their peers and students, to this appropriation of reality, to analyze it critically, in the light of theories. This conceptual walk will certainly be a path for proposing new experiences". 


\section{Narratives as Teacher Educator's: Formative Trajectory Woven in Colaboration}

The data obtained in the actions developed during the research and analyzed through the narratives were configured in: a) Planning and development of teaching practices articulated between the disciplines; b) SCP as a space for initial and continuing teacher training in an integrating perspective of the teaching, research and extension tripod; c) Praxis articulated to the daily life of the school in the lens of the students.

\subsection{Planning and Development of Teaching Practices Articulated between Disciplines}

Planning is an essential action, necessary not only in the educational space, but throughout life. "It is, therefore, a fundamental act for the successful implementation of the proposed actions, which includes theoretical and practical knowledge programmed with the purpose of reaching the proposed objectives and goals" (Paniago, 2017: p. 94).

We will focus here on the teaching planning of the subjects taught by us in the undergraduate teaching courses in Biological Sciences and Chemistry, namely, the disciplines of the pedagogical dimension field: Didactics, Socio-Historical Foundations of Education, Philosophical Foundations of Education, Public Policies of Brazilian Education and Teaching Practice in Chemistry and Biological Sciences.

We defend the need and importance of planning, as a means of programming teaching action, as a continuous action of "[...] analyzing the conditions (possibilities and weaknesses) in a given situation; decision making about the best way to go" (Paniago, 2017: p. 94). Planning in our understanding presupposes decision-making anchored in ethical and political principles, revealing the social commitment of teachers with training for citizenship in which the political sense of planning translates into the commitment to social transformation, with the training of students to act with decision-making power, critically and reflexively in the environment in which they operate.

So, as teacher educators, when planning, we ask: what is the purpose of teaching this or that content? In what sense are we going to contribute to the critical and political training of our undergraduates, future teachers of basic education? It is important to note that, in planning (teaching or lesson plan), the objectives are fundamental, as they are the ones that will define the content and didactic strategies to be worked on in the classroom.

Anchored in this vision of planning, each academic semester, amid the sagacious logistics and labor consuming in the teaching/research/extension tripod which consumes our time for long hours daily, we try to dispense a space to weave, collaboratively, articulating actions in our planning. In general, in addition to seeking to articulate the knowledge worked in the classroom, we adopted, in our planning, didactic strategies with a view to an intersection between the 
disciplines we teach, ranging from dynamics of study in class, books and articles chosen, work with films and videos, to technical visits.

From the point of view of using theoretical references, we try, as far as possible, to use the same book to work with the disciplines we teach, in order to encourage students to read comprehensively, interpretively, analytically and reflexively the same book with the lenses of different areas of knowledge. For example, we used the book, O que é educação, by Carlos Rodrigues Brandão to work with the disciplines of Socio-Historical Foundations of Education and Philosophical Foundations of Education. Therefore, in Philosophical Foundations, we worked on the initial chapters of the book: "Educação, Educações: aprender com o índio", "Quando a escola é a aldeia", "Então, surge a escola", "Pedagogos, mestres-escola e sofistas", "A educação que Roma fez, e o que ela ensina", and in Socio-Historical Foundations, we continued working on the following chapters: "Educação: isto e aquilo, e o contrário de tudo", "Pessoas versus sociedade: um dilema que oculta outros", "Sociedade contra Estado: classe e educação", "Esperança na educação".

In this perspective, we also provide teaching practices aimed at the theoretical problematization of the school context, through shared readings of essential books for the discussion and understanding of school education, such as the books by Paulo Freire "Pedagogia do Oprimido" and "Educação e Política", "Escola sem Partido", organized by Frigotto (2006), among other authors, such as: Demerval Saviani and Libâneo. The debates of the readings seek to unsettle students about the different nuances present in the school with the theoretical deepening of the issues that permeate education. We observed, with the readings, that the critical reflection of the school reality based on the theory becomes fundamental and emergent for the formation of the teaching professional identity. Thus, we focus on the everyday pedagogical practices of teaching, aiming at the mobilization and re-elaboration of knowledge, through critical reflection on the practice, also building its teaching identity.

Nevertheless, in the classroom, we try to adopt didactic postures that are consistent with our planning and that are consistent with our teaching and education vision. Thus, we try to give learning autonomy to students, encouraging them to have an active performance in the classroom, which translates into working with several didactic strategies that are not centered on the expository class using a blackboard or data show. On the contrary, we seek to mobilize a pedagogy of content in the classroom (Shulman, 1987; Paniago, 2017) which, in addition to facilitating the learning of the theoretical contents worked on, encourages undergraduate students to produce capacity.

Our way of working begins with class organization, which no longer focuses on traditional organization, with students lined up, "eyes on the necks of their colleagues", with no possibility of dialogue and looking into each other's eyes. On the contrary, we organize the portfolios in circles and position ourselves also in it, in order to enable dialogue between students, to look at themselves and 
others in an affective way, in order to get to know each other and, above all, we try to demonstrate that, being teachers, our position is one of affection, dialogue and learning, because while we teach, we also learn and live, in a dialogical way, with people who, before being students, are human beings who deserve our respect and affection.

[...] It is necessary that, on the contrary, from the beginning of the process, it becomes increasingly clear that, although different from one another, those who form and are re-formed by forming and those who are formed are formed and form when being formed. [...] There is no teaching without discourse, the two explain themselves and their subjects, despite the differences that connote them, are not reduced to the condition of object, each other. Whoever teaches learns when teaching and whoever learns teaches when learning [....]. (Freire, 2006: p. 23)

In addition, we address several other strategies that encourage students to be active in their learning, such as: portfolio, seminar, discussion and debate, concept map, simulated jury, film analysis ${ }^{2}$, project work, among others. For the use of these strategies, we rely on our production, Paniago (2017), in Anastasiou \& Alves (2004), Vieira and Vieira (2005).

The portfolio was built by the licensors during the semester, through a process of identification, analysis, selection, reflection and registration of the most significant productions of the subjects worked on. We use the Portfolio as an instrument in the pedagogical process and as an evaluation instrument, considering two dimensions: 1) as teachers, we evaluate the learning performance through the final product to be presented at the end of the semester; 2) at the end of the semester, the licensee evaluates his own learning and gauges a grade. Nevertheless, the Portfolio aims to collaborate to develop its capacity for reflection and writing, considering that the portfolio is "[...] a set of documents carefully selected, significantly commented and systematically organized" (Alarcão, 2011).

The Simulated Jury consists of a simulation of a jury in which, based on a problem, defense and accusation arguments are presented (Anastasiou \& Alves, 2004). For its use, we present a case or theme to be analyzed by students from the theoretical knowledge studied in the discipline. They will dramatize a situation and, therefore, involve the entire room (a judge, two clerks, prosecutors, defense, sentencing council, plenary, among others). Aiming to promote the involvement of the entire classroom, students generally seek, initially, to dramatize the case that occurred, and then take it to the simulated court.

That said, we believe that our praxis encourages undergraduates to also assume different didactic postures to be mobilized as future educators, some of which are already operationalized in training through insertion in daily life at

${ }^{2}$ Some films are used in our classes: "A luta por um ideal” (Won't back down); "Escola da Vida" (School of life); Divertida Mente" (Inside Out); "Quando eu sinto que já sei”; "Como Estrelas na Terra" (Taare Zameen Par). 
school, as we will discuss later.

\subsection{The SCP Space for Initial and Continuing Teacher Training in an Integrating Perpective of Teaching, Research and Extension}

In 2015, the CNE (National Education Council), through CNE Resolution No. 2/2015, of July 1, defined the DCN/2015 (DCN, National Curricular Guidelines) for initial and continuing training. In this resolution, it is stated that the SCP, a compulsory curricular component in all degrees, which starts from the second half of the course, must be developed in conjunction with the daily life of the basic education school and must permeate the other activities of the undergraduate teaching courses. Thus, the SCP is a mandatory curricular component and aims to develop teaching knowledge through the articulation of theory and practice and the experience of teaching work situations, as stated by Paniago e T. Sarmento (2015), SCP is important, “[...] for making it possible for the trainee to get closer to their future profession, to allow them to experience teaching practices, to establish the theory-practice relationship, to live with the complexity of everyday school life and, above all, to experience educational interaction practices with students" (Paniago \& Sarmento, 2015: p. 77).

Thus, when considering the importance of SCP for the learning of teaching of future teachers, it is essential that they take effect, through collaborative and articulated actions in the various disciplines that make up the curriculum of the course, as a way to overcome the problems existing in our country. internship system already verified by us:

The lack of articulation between the theory and the practice of the internship translates a formative process based on technical rationality. This lack of articulaton may be verified between the various disciplines that make up the matrix of the undergraduate courses, added to the absence of planning and collective reflection among the teachers who educate the HEI, and of these with the holders of the education class basic (Paniago \& Sarmento, 2015: p. 94).

In the expectation of advancing from this formative perspective, we are developing teaching practices that are articulated between the disciplines we teach and linked to the daily routine of the basic education school through the implementation of the tripod: teaching, research and extension operationalized with undergraduate students who are enrolled at SCP and in disciplines that we teach.

For this, in addition to the articulated and collaborative planning, as mentioned, we get together constantly to evaluate our actions and study theoretical references that support our work. Nevertheless, every three weeks, we have a meeting with all the participants of the teaching, research and extension projects that we coordinate. In addition, we also get together with the basic education school teachers and collaborators in the projects, because we believe that the training articulated to school does not become effective without appropriate dialogue with the supervising teachers who are co-trainers of future teachers. In 
addition, we must bear in mind that the SCP is a possibility of continuous training for all those involved: we, teacher trainers, and for the teachers who are in school helping as co-trainers. According to Pimenta and Lima (2017: p. 107), "the supervisory activities that take place in the internship require approximation and distance, knowledge sharing, capacity for complementation, evaluation, counseling, implementation of hypotheses to solve the problems that, collectively, are faced by interns".

From 2017 to 2019, the following extension and research projects were developed linked to the disciplines we teach classes: Alternatives for improving the teaching-learning process in undergraduate courses: bringing graduates closer to the professional context; The collaborative production of didactic-pedagogical materials and their use in basic education schools; Ethnic-Racial Relations and School: teaching methodologies for investigating racismo confrontation.

The teaching project "Alternatives for improving the teaching-learning process in undergraduate courses through professional insertion practices for undergraduate students" aimed to seek alternatives to improve teaching-learning in undergraduate courses, through collaborative work that enables the operationalization of the discipline "Practice as Curricular Component (PCC)" and Internship as core and articulating elements in training. The operationalization of this project took place through a formative work among teachers of some of the disciplines and undergraduates of the Biological Sciences and Chemistry courses and teachers of basic education. To this end, some activities were developed: analysis of the level of education of didactic books used by the undergraduates in order to identify the possibility of correlation of the contents and teaching methods to be developed in the subjects of the Bachelor's degrees; formative meetings of the participating team to study issues involving education and its role, teaching planning, evaluation process, alternative methodologies (active, developmental, meaningful learning, etc.), different didactic-pedagogical strategies and alternatives to be applied in undergraduate courses and in the teaching of Science, Chemistry and Biology in basic education; insertion of undergraduate students in the basic education school through investigative intervention projects. For the elaboration of the projects, based on a dialogue with basic education teachers, we listed a generative theme. For example, we work with healthy eating, Interdisciplinary Teaching Practices for Science Education and Ethnic-Racial Relations and Science Pedagogy through the Environmental Education perspective.

The research project "The collaborative production of didactic-pedagogical material and use in basic education schools" aimed to identify science content in elementary schools where students have presented greater difficulty with and to build educational didactic material to work on this content. To this end, the following activities were carried out: interviews to identify contents that are difficult for students to understand and are related to the disciplines of Science, Biology and Chemistry with two schools of basic education in Rio Verde; Con- 
struction and application of teaching materials in primary schools.

The extension and research project "Ethnic-racial relations and school: teaching methodologies for investigating the fight against racism" aimed to propose teaching methodologies in the final years of elementary school, in order to investigate possible actions to prevent discrimination. and ethnic-racial prejudice in school daily life. The Project, materialized in actions, sought to stimulate the reflection of students so that they may become multipliers of opinions contrary to racial prejudice. Throughout the project, several actions were carried out, such as: a theoretical study on the theme; bibliographic survey in the campus library in order to identify whether the campus offers literature on the subject; survey of data from the Brazilian Institute of Geography and Statistics (IBGE) on black people in the municipality of Rio Verde; mini storytelling course, for the purpose of telling stories of Afro-Brazilian culture in municipal schools; creation of a webpage linked to Facebook, to provide information and dialogue with the student community; elaboration of the project's documentary video; Poetry soiree for the internal and external campus community to present the video produced.

Thus, in articulation with the disciplines we teach, the projects aimed to bring undergraduates closer to the school floor, considering that, as Canário (2001) explains, it is in the "shuttle" between the spaces of the university and the school, or between training and work, which can effectively articulate the theoretical knowledge and the knowledge of the experience guiding the teaching learning articulated with the school's daily life, through the SCP, seen in an investigative and questioning view. Pimenta and Lima (2017: p. 105) also point out the need for the activities developed in the training course to consider "[...] the internship as a privileged space for questioning and investigation".

In previous research, we presented, "[...] the results of action research carried out with undergraduate students in Chemistry and Biological Sciences at the Instituto Federal Goiano, in which the goal was to analyze how research in teacher education allows for the approximation of future teachers in basic education school" (Paniago et al., 2020: p. 1).

Below, we will present some of the activities developed through the eyes of the undergraduates.

\subsection{Praxis Articulated to the Daily Life of the School through the Eyes of the Students}

To begin with, we emphasize our understanding of praxis as the materialization of theory-practice, that is, the way in which undergraduate students will think about the practical elements of teaching, about the emblematic issues of the teaching-learning process, embedded in theory, which means problematize, analyze and intervene in the elements of practice in the light of theoretical elements. We rely on Pimenta and Lima (2017), when defending the teacher as a critical-reflexive intellectual, which implies the exercise of reflection subsidized by theory with a 
view to the transformation of pedagogical practice through the transformation of the teacher.

For the insertion of undergraduates in the daily life of the school, as we have already stated, from the umbrella projects mentioned above, they elaborated teaching projects, having as their motto, the approach to the school perspective in an investigative and questioning view.

Furthermore, we present some narratives of the undergraduates, from the experience in 3 basic education schools, some of whom are participants in the teaching, research and extension projects, interns, and the subjects we taught in 2017 and during the first semester of 2019. The narratives were collected in the portfolios developed in the disciplines.

As some of the activities took place during the day, not all undergraduates were able to participate due to their working hours. However, we try, in the classroom, to provide a space for the participants of the projects to narrate the teaching/learning situations experienced in the developed projects, based on the studied knowledge. Thus, when socializing their experience in the daily life of the school, the undergraduates reflected on the situations experienced and shared them with the other colleagues, who, perhaps, never experienced the complex and heterogeneous situations of the school as graduating.

Thus, when considering the number of projects and the length of this text, we chose to highlight the activities of a project developed in the second half of 2017 and the first of 2018, with a view to achieving the relationship between teaching, research and extension, involving interns and other undergraduates, based on the theme healthy eating. The project ${ }^{3}$ was built collectively and developed in groups, formed preferably by those who were in the ECS and those who were not, so that those who were in the ECS, mediated the insertion of the others in the school environment, as well as conducted the dialogue between the supervising professor with a view to promoting space for carrying out intervention practices. A Biological Sciences intern testifies:

After the initial survey, in dialogue with the class teacher, some themes were selected that would be worked on in the $4^{\text {th }}$ bimester, a period in which practices could be carried out using elaborated didactic strategies. The highlighted contents were "Nutrition: composition of food and importance of nutrients in the body, and food pyramid". Based on this theme, it was possible to intervene cooperatively with the classroom teacher based on projects. (Tamara, School A, 2018)

A Chemistry graduate who worked with the pyramid practice tells how the activity was: For the development of the food pyramid practice, we seek subsidies

\footnotetext{
${ }_{3}^{3}$ In the projects developed in the classroom in the years 2017 and 2018, we work with the theme healthy eating. Students developed several educational actions in schools involving different didactic strategies: games, music, theater, concept maps, among others. In addition, the participating schools also came with the students to the Federal Institute to participate in practices in various educational environments and with the use of various teaching strategies developed by the undergraduate students. The activities involved all students of the disciplines that we teach classes.
} 
related to the topic of nutrition worked in the $3^{\text {rd }}$ bimester. We found an updated food pyramid in a literary document from the FI (Federal Institute) of Triângulo Mineiro (Fernando, School C, 2018). The licensee signals the way in which he built the didactic material: I constructed the outline of 15 food pyramids on sulfite paper, leaving the point for students to glue images of the specific foods of each gap in the pyramid. According to him, the experience was gratifying, as it was possible to realize how much students can respond positively when there is effort employed (Fernando, School C, 2018).

In her turn, another undergraduate affirms the collaboration of the supervising professor in the process of carrying out the activities:

After making a diagnosis, the first practical action was developed together with the Science teacher, whose objective was to streamline the work of the teaching-learning process of the program content with the students being "Healthy eating". To carry out this action, we seek to encourage students to produce and actively participate in the teaching-learning process. So, initially, it was suggested that students make informative posters on the topic. The posters were displayed on the school mural, and during its preparation, subjects about the composition of food were discussed. (Taila, School A, 2017)

As indicated by the undergraduate student, there was a concern with the teaching-learning of students in an active way, in participating, concretely, in their way of learning and building new knowledge.

In addition, the participation of the teacher in the process of preparing the planning and proposing actions in the classroom is signaled, which highlights the importance of the supervising teacher in his training. We use Pimenta and Lima (2017) here, when they state that the trainee's transition from the training institution to the school and vice versa allows for the construction of a network of relationships, knowledge and learning

"[...] not with the aim of copying, of criticizing only the models, but in the sense of understanding reality in order to overcome it. Learning from professors by profession what teaching is like, what it is like to teach, is the challenge to be learned/taught during the training courses and on the internship." (Pimenta \& Lima, 2017: p. 105)

Certainly, the activities carried out gave future teachers contact with teaching practices in basic education, therefore, they experienced several teaching learning situations, which go from contact with school situations to classroom teaching practices. class, in which we will highlight some elements that constitute the teaching praxis, which are the teaching methods, the teacher-student relationship.

However, another Biological Sciences undergraduate student highlights his perception of the insertion in the school's daily life. These activities helped me to think about my future practice as an educator, as it is possible that my students 
learn in a fun way and that the learning space goes beyond a classroom [...]". And the undergraduate goes on to say that "It was a positive experience. We observed that the practices were well accepted and that the students liked the proposed activities. As future teachers, we had the opportunity to get closer to the school environment by applying various practices and evaluating the results (Paulus, School B, 2017).

Another undergraduate student, also in Biology, points out that: This activity helped me to think about my future practice as an educator, because in addition to having learned to elaborate a lesson plan and know how to apply it in a classroom, as well as to understand the difference between a general objective for a specific objective, I learned what it is to be an education professional and that he has to be prepared to deal with the diverse impactful realities of everyday life (Nanes School A, 2017).

The undergraduates, in addition to claiming that the experience in the classroom helped them to think about their future practice as educators, highlight elements about the conditions of the basic education school: seeing the reality of the School, I realized the great weakness of Brazilian education, mainly the lack of financial resources to provide a better physical environment, among other needs of students, who are also low class majority, and have their difficulties and limitations outside school (Loura, School B, 2017). In turn, the narrative of another undergraduate student corroborates by pointing out that this practice was crucial for my future activity as an educator, when I came across children in such a hot and cramped place, full time, and yet so happy, active and affectionate with the school professionals, I was able to understand how fundamental a teacher can be in someone's life (Branca, Escola B, 2017).

As noted, the undergraduates' narratives signal special elements of the students' context, the school structure, students' affection issues, in short, the school's particularities. In this sense, we corroborate to Pimenta and Lima (2017: p.104), when they explain that "learning the teaching profession during the internship requires special attention to the particularities and interfaces of the school reality in its context in society. Where is the school located? How are your students? Where do they live? [...] "

\section{Final Considerations}

In our research trajectory, by intending to present some elements that contribute to the articulated planning between the disciplines, highlighting the contributions of the Supervised Curricular Internship (SCI), as an element that enables the connection between the teaching, research and extension tripod and the future field undergraduate students' work, it became possible to focus on our praxis and reflect how we, as teacher educators, can develop teaching practices in a collaborative way aimed at teaching how to teach in undergraduate courses. We realized that the teacher lacks, due to the nature of his/her work, to materialize a scientific training, due to the bias of the articulation between theory and 
practice, and, above all, by the teaching, research and extension tripod. In this way, the true meaning of praxis is constructed, as a transformative action sustained by the knowledge of reality and reflection on it, which can overcome the challenges present in the school context and strengthen the historical sense of teaching. Therefore, they combine the conception of practices that seek knowledge of the social conditions of education, providing opportunities for planning aimed at the search for concrete alternatives for teacher training.

We defend the premise that the training of teachers envisaged in collaborative and investigative practices can and should be developed from the beginning of the course, putting into effect what the normative documents foresee in the pedagogical political projects of the undergraduate courses point out, both in the articulation of the disciplines by planning together, in the work with the disciplines that provide the practice as a curricular component (PCC), as in the SCI.

However, it is necessary that some challenges are faced. Immediately, the ways of organizing the development of teaching practices in the disciplines and in the SCI need to be considered, through dialogue and carrying out actions with the schools of basic education, the future field of action of the undergraduate students. In this proposal, there is a direct impact, both in the training offered at the HEIs, in the school curriculum, as well as in the relationship of the school and its actors, with the other social institutions, insofar as these are also constituted in educational spaces. In this articulation process, the supervising teachers of the SCI field schools stand out, who effectively contribute to the professional construction of undergraduate teachers, since they appreciate and participate in the training opportunities provided at the Federal Institute, Education Center. The SCI, therefore, should be marked out in order to include the valorization and approximation made operationally by the dialogue between the undergraduate students in training with the teachers of the rural schools.

The need for a redirection in the collaborative planning between the subjects of the initial teacher training courses is evident, as well as a training process that is organically articulated to the school routine, in order to be able to provide material, professional and intellectual conditions capable of ensuring the teachers a teaching performance in the perspective proposed here.

This research signaled the importance of collaborative planning and training practices that bring investigative students closer to their future field of work. However, these practices cannot be limited only to teachers who train in the field of education, it is necessary that all teacher educators were committed to such practices. So, for the continuity of the research, we ask ourselves: How to involve the teacher educators of specific areas in a collaborative planning between the disciplines and articulated to the daily life of the basic education school?

\section{Acknowledgements}

To the Goiano Federal Institute for the support. 


\section{Conflicts of Interest}

The authors declare no conflicts of interest regarding the publication of this paper.

\section{References}

Abrahão, M. H. M. B., \& Maria da Conceição, P. (2012). As Narrativas de Formação, a Teoria do Professor Reflexivo e a Autorregulação da Aprendizagem: Uma Possível Aproximação. In: A. M. Veiga Simão, L. M. Frison, \& M. H. M. B. Abrahão, (Eds.), Autorregulação da Aprendizagem e Narrativas Autobiográficas. Epistemologia e Práticas ( $3^{\text {a }}$ ed., pp. 53-71). Vol. 1, Natal/Porto Alegre/Salvador: Editora da UFRN/Editora da PUCRS/Eduneb.

Alarcão, I (2011). Professores Reflexivos em Uma Escola Reflexiva (8th ed.). São Paulo: Cortez, 2011.

Anastasiou Léa das Graças Camargos, A., \& Alves, L. P. (2004) Estratégias de Ensinagem. In A. Léadas Graças Camargos, \& L. P. Alves (Eds.), Processos de Ensinagem na Universidade: Pressupostos Para as Estratégias de Trabalho em Aula (3rd ed., pp. 67-100). Joinville: Univille.

André, M., Almeida, P., Hobold, M., Ambrosetti, N., Passos, L., \& Lúcia Manrique, A. (2010). O Trabalho Docente do Professor Formador no Contexto Atual das Reformas e das Mudanças no Mundo Contemporâneo. Revista Brasileira de Estudos Pedagógicos, 91, 122-143. https://doi.org/10.24109/2176-6681.rbep.91i227.606

Brzezinski, I. (2011). Profissão Professor: Identidade e Profissionalização Docente. Brasília: Plano Editora.

Canário, Rui. (2001). A Prática Profissional na Formação de Professores. In: B. P. Campos (Ed.), Formação Profissional de Professores no Ensino Superior, Porto: Porto Editora.

Diniz-Pereira, J. E.(2016). Da Racionalidade Técnica à Racionalidade Crítica: Formação Docente e Transformação Social. Perspectivas em Diálogo: Rev. Educ. Soc, Naviraí, 1, $34-42$.

Flores, M. A. (2000) Currículo, Formação e Desenvolvimento Profissional. In: J. A. Pacheco (Ed.), Políticas de Integração Curricular (pp. 147-166). Porto: Porto Editora

Freire, P. (2006). Pedagogia da Autonomia (34a. ed.). São Paulo: Paz e Terra.

Frigotto, G. (org.) (2006). Escola "sem" partido: Esfinge que ameaça a educação e a sociedade brasileira (144 p.). Rio de Janeiro: UERJ, LPP.

Gatti, B. A. (2010) Formação de Professores no Brasil: Características e Problemas. Educação e Sociedade, 31, 1355-1379. https://doi.org/10.1590/S0101-73302010000400016

Gómez, A. P. (1997). O pensamento prático do professor: A formação do professor como profissional reflexivo. In A. Nóvoa, (Org.), Os professores e a sua formação (3a ed., pp. 93-114). Lisboa: Dom Quixote.

Imbernón, F. (2016) Qualidade do Ensino e Formação do Professorado: Uma Mudança Necessária. Tradução, Silvana C. Leite. São Paulo: Cortez.

Josso, M.-C. (2010). Experiência de Vida e Formação. São Paulo: Paulus.

Mizukami, M. G. N. (2013). Escola e Desenvolvimento Profissional da Docência. In: B. A., Gatti, et al. (Eds) Por uma Política Nacional de Formação de Professores (pp. 23-54). São Paulo: São Paulo State University.

Paniago, N. R. (2017). Os Professores, seu Saber e o seu Fazer: Elementos Para Uma Reflexão Sobre a Prática Docente. Paraná: Editora Appris. 
Paniago, R. N. (2016) Contribuições do Programa Institucional de Bolsa de Iniciação para a Aprendizagem da Docência Profissional. Tese de Doutorament, Braga: Universidade do Minho.

Paniago, R. N., \& Sarmento, T. (2015). O Processo de Estágio Supervisionado na Formação de Professores Portugueses e Brasileiros. Revista Educação em Questão, 53, 76-103. https://doi.org/10.21680/1981-1802.2015v53n39ID8521

Paniago, R. N., Nunes, P. G., Suely Ribeiro Cunha, F., da Silva Sales, P. A., \& Junior de Souza, C. (2020) Quando as Práticas da Formação Inicial se Aproximam na e pela Pesquisa do Contexto de Trabalho dos Futuros Professores. Ciência \& Educação (Bauru), 26, e20047. http://dx.doi.org/10.1590/1516-731320200047

Paniago, R. N., Sarmento, T., Medeiro, S. J., \& Nunes, P. (2018). Um Cenário de Possibilidades Para o Estágio Curricular Supervisionado no Contexto de um Instituto Federal. Ensaio Pesquisa em Educação em Ciências (Belo Horizonte), 20, e11044. http://dx.doi.org/10.1590/1983-211720182001022

Pimenta, S. G., \& Lima, M. S. L. (2017). Estágio e Docência (8ª ed.). São Paulo: Cortez

Shulman, L. S. (1987). Knowledge and Teaching: Foundations of the New Reform. Harvard Educational Review, 57, 1-23. https://doi.org/10.17763/haer.57.1.j463w79r56455411

Tardif, M. (2013). Saberes Docentes e Formação Profissional (15 ed.). Petrópolis, RJ: Vozes.

Vieira, R., \& Vieira, C. (2005). Estratégias de Ensino/Aprendizagem. Lisboa: Instituto Piaget. (Coleções Horizontes Pedagógicos).

Zeichner, K. M. (2008). A Pesquisa-Ação e a Formação Docente Voltada Para a Justiça Social: Um Estudo de Caso dos Estados Unidos. In: J. E. Diniz-pereira, \& K. M. Zeichner (eds.), A Pesquisa na Formação e no Trabalho Docente (2a ed., pp. 67-94). Belo Horizonte: Autêntica. 